\title{
The role of kisspeptin in reproductive function in the ewe
}

\author{
Jeremy T. Smith'1 ${ }^{1}$ Penelope A.R. Hawken², Michael N. Lehman ${ }^{3}$ and \\ Graeme B. Martin²
}

'School of Anatomy, Physiology and Human Biology, The University of Western Australia, Western Australia 6009, Australia; ${ }^{2}$ School of Animal Biology, The University of Western Australia, Western Australia 6009, Australia; ${ }^{3}$ Department of Neurobiology and Anatomical Sciences, University of Mississippi Medical Center, Jackson, MS 39216, USA

\begin{abstract}
Summary
Kisspeptin is a hypothalamic neuropeptide that is critical for fertility. In virtually all species, kisspeptin neurons stimulate gonadotrophin-releasing hormone $(\mathrm{GnRH})$ secretion and act as transmitters for sex-steroid feedback to GnRH neurons. In sheep, kisspeptin neurons are located in the preoptic area and the arcuate nucleus (ARC), with the latter involved in both oestradiol positive and negative feedback regulation of $\mathrm{GnRH}$. In addition, sheep are seasonal breeders, with an annual cycle controlled by changes in the pulsatile secretion of $\mathrm{GnRH}$. Kisspeptin neurons are also important in this phenomenon showing increased expression and terminal apposition to GnRH neurons during the breeding season. Reduced kisspeptin expression during the non-breeding season can be overcome by administration of kisspeptin, which causes ovulation in seasonally acyclic females. On the other hand, kisspeptin neurons do not appear to express the melatonin receptor, so the transduction of photoperiod to these neurons must be indirect, perhaps involving dopaminergic suppression during the non-breeding season. Importantly, kisspeptin neurons of the ARC do not operate in isolation. Autoregulation of kisspeptin expression by the neuropeptides neurokinin B and dynorphin is a key contributor to the "KNDy neuron" concept and the hypothesis that these neurons comprise the GnRH pulse generator. Indeed, the pheromone-induced interruption of seasonal anestrus, known as the male effect, appears to be mediated by KNDy signalling. However, the 'KNDy hypothesis' for $\mathrm{GnRH}$ pulse generation is still unproven and, indeed, the precise role of KNDy cells in seasonal breeding has yet to be determined.
\end{abstract}

\section{Introduction}

In mammals, the reproductive process is governed through intricate neural and hormonal communication between the brain, pituitary gland and gonads. At the top of this hierarchical regulatory system is the release of gonadotrophin-releasing hormone $(\mathrm{GnRH})$ pulses from neurons in the preoptic-hypothalamic continuum that are obligatory for the secretion of luteinizing hormone (LH) pulses from the anterior pituitary gland (Clarke \& Pompolo 2005). Changes in the frequency or amplitude of $\mathrm{GnRH}$ pulses have a profound effect on the reproductive system, so it is not surprising that the origin and control of the pulsatile pattern have been the focus of research for nearly four decades (Martin 1984, Clarke 2011). One major puzzle has been the fact that, in both sexes, sex steroids are major drivers of change in the pulsatile release of $\mathrm{GnRH}$, yet $\mathrm{GnRH}$ neurons lack the receptors responsible for steroid feedback control. This

Corresponding author E-mail: jeremy.smith@uwa.edu.au 
conundrum led to a prolonged search for cells that could fill this gap in communication between the gonads and the brain's GnRH neurons. Many candidates, focused within the mediobasal hypothalamus (Blache et al. 1991, Caraty et al. 1998), with both inhibitory and stimulatory effects on GnRH secretion, have been assessed (Clarke \& Pompolo 2005), and kisspeptin is currently leading the field.

In sheep, there is also an annual pattern in reproduction that is controlled primarily by the annual photoperiodic cycle, with modulation by other inputs such as nutrition and socio-sexual signals (Scaramuzzi \& Martin 2008). The photoperiodic cues are perceived and translated into a key physiological signal that is mediated through the secretion of melatonin from the pineal gland during periods of darkness. Melatonin cannot act on $\mathrm{GnRH}$ neurons directly (Goodman et al. 2010) so, as for the sex steroids, melatonin appears to need other cells within the mediobasal hypothalamus (Malpaux et al. 1998, Migaud et al. 2005) to exert its influence on $\mathrm{GnRH}$ secretion. Nevertheless, GnRH and LH pulses appear to be the over-riding determinant of seasonal reproductive function. Photoperiod-driven changes in pulsatile $\mathrm{GnRH}$ secretion are evident in both oestradiol negative feedback independent and dependent mechanisms (Karsch et al. 1980, Martin et al. 1983). The former is evidenced by a change in LH pulse frequency in ovariectomised (OVX) ewes, the latter by a profound increase in responsiveness to oestradiol negative feedback on GnRH/LH during the non-breeding season (Fig. 1). Thus, neuropeptides governing the pulsatile release of $\mathrm{GnRH} / \mathrm{LH}$, and/or those involved in transmitting oestradiol negative feedback signals to GnRH neurons, are likely to be key systems in the control of the seasonal reproductive pathway. Again, kisspeptin is currently leading the field.

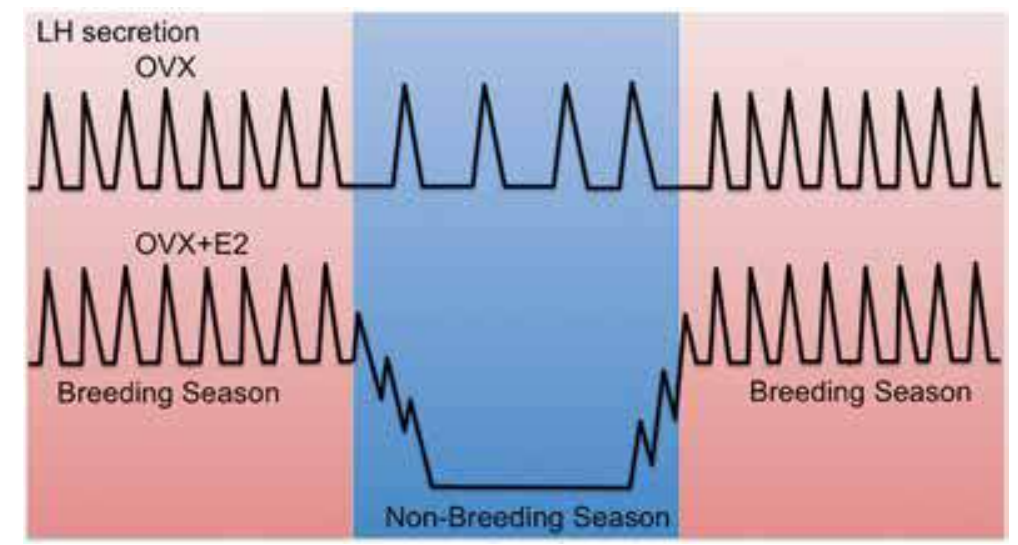

Fig. 1. Schematic representation of the seasonal change in LH secretion in ewes. LH profiles are shown for ovariectomised (OVX) ewes and OVX plus oestradiol (E2) treated ewes - demonstrating the oestradiol independent and dependent mechanisms for seasonal regulation of $\mathrm{GnRH} / \mathrm{LH}$ secretion. The figure is derived from Karsch et al. (1980).

\section{Kisspeptin}

There is absolutely no doubt that kisspeptin, the product of the Kiss 1 gene, and its receptor, Kiss1r (previously Gpr54) play a major role in the control of GnRH secretion (Gottsch et al. 2004, Oakley et al. 2009). In sheep, the evidence for this includes: i) kisspeptin neurons project to $\mathrm{GnRH}$ neurons (Smith et al. 2008); ii) virtually all GnRH neurons express KISS1R mRNA (Smith et al. 2009a); iii) kisspeptin rapidly and robustly stimulates $\mathrm{GnRH}$ and gonadotrophin secretion (Smith et al. 2011); iv) kisspeptin neurons are located in regions of the hypothalamus 
involved in sex steroid feedback (including the arcuate nucleus, ARC) in both males and females, and express oestrogen, progesterone and androgen receptors (Lehman et al. 2013); and v) in turn, sex steroids, particularly oestradiol, regulate kisspeptin neurons in a manner consistent with negative and positive feedback effects on GnRH neurons (Smith 2013), vital for tonic gonadotrophin secretion and the preovulatory LH surge.

In sheep, kisspeptin neurons are found in the preoptic area (POA) and the ARC, as shown with in situ hybridization (Estrada et al. 2006, Smith et al. 2007) and immunohistochemistry (Franceschini et al. 2006, Smith et al. 2008) (Fig. 2). Expression of KISS1 mRNA in the ARC increases after ovariectomy in ewes, and is normalized in ovariectomized ewes after chronic oestradiol replacement (Smith et al. 2007, Smith et al. 2008). Chronic progesterone replacement also inhibits KISS1 expression in ovariectomized sheep (Smith et al. 2007). Virtually all kisspeptin neurons in the ovine ARC co-express oestrogen receptor alpha (ESR1) and progesterone receptor (Franceschini et al. 2006, Smith et al. 2007) and steroid-sensitive neurons projecting from the ARC have been implicated for a role in the negative feedback control of GnRH secretion by oestradiol (Blache et al. 1991, Caraty et al. 1998, Simerly 2002). In sheep, the ARC is also thought to relay oestradiol positive feedback signals to $\mathrm{GnRH}$ neurons (Blache et al. 1991, Caraty et al. 1998). Again this appears to be mediated by kisspeptin neurons because kisspeptin gene expression and peptide production are increased in the ARC, particularly the middle-to-caudal areas, during the late-follicular phase of the oestrous cycle (Estrada et al. 2006, Smith et al.

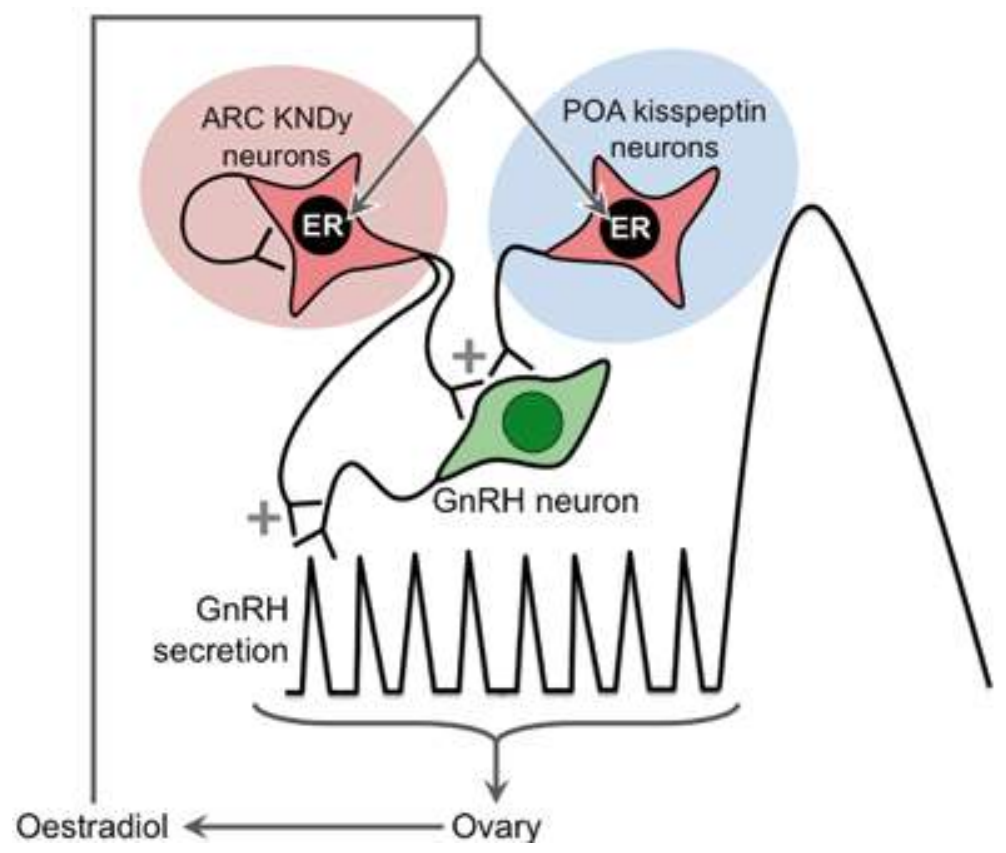

Fig. 2. The proposed anatomical relationship between kisspeptin and GnRH neurons in the ewe. Caudal kisspeptin neurons in the arcuate nucleus (ARC) co-express neurokinin $\mathrm{B}$ and dynorphin and are thus termed "KNDy" neurons. KNDy neurons appear to project to both the GnRH neuron cell body (Lehman et al., 2013) and GnRH terminals in the median eminence (Smith et al., 2011) to participate in both GnRH pulsatile secretion and the preovulatory LH surge. Rostral kisspeptin neurons located in the preoptic area (POA) project directly to GnRH neurons (Backholer et al., 2009) and appear to solely participate in the preovulatory LH surge. Both populations express oestrogen receptor alpha (ER) and modulate oestradiol feedback. 
2009a). Moreover, kisspeptin neurons in the middle and caudal ARC show robust induction of FOS (a marker for neuronal activation) following a surge-inducing oestradiol injection (Smith et al. 2009a, Merkley et al. 2012). How this single population of neurons responds to oestradiol, but with two opposing outcomes, has puzzled researchers in the kisspeptin field. Data from studies with mice suggest alternative intracellular pathways (genomic vs non-genomic) post-ESR1 binding (Gottsch et al. 2009) but such observations only provide few clues for the ovine model. It is however possible that an indirect, multi-synaptic activation pathway rather than direct effect of oestradiol is central to the preovulatory LH surge generation in ewes. A temporal aspect to the oestradiol response has also been proposed (Clarke \& Caraty 2013). Central to this hypothesis is that the positive feedback event is transient, but negative feedback is continuous. Thus, an acute rise in oestradiol temporarily activates the ARC kisspeptin cells culminating in the LH surge, while constant levels of oestradiol inhibit the activity of ARC kisspeptin neurons (Smith et al., 2009a). Given the current data in the sheep, this appears to be the most feasible explanation.

Kisspeptin neurons in the POA are now also known to play an important role in mediating positive feedback in sheep (Smith et al. 2009a, Hoffman et al. 2011, Merkley et al. 2012), suggesting a parallel with the rostral population of kisspeptin neurons in rodent species, located in the anteroventral periventricular (AVPV) region. In both neuronal populations, oestradiol can stimulate the expression of Kiss 1 mRNA (Smith et al. 2005, Smith et al. 2006, Smith et al. 2008). Importantly, the positive feedback mechanism in ewes does not change between breeding seasons. Thus, during seasonal anoestrus, increased oestradiol negative feedback prevents the sequence of events leading to positive feedback, but the neuroendocrine ability to produce a surge is intact (Clarke 1988).

It is clear that sex steroids are major regulators of kisspeptin neurons in the ARC. Focusing on negative feedback, which is pivotal for the pulsatile release of $\mathrm{GnRH}$, a strong case can be made for these steroid-responsive kisspeptin neurons playing a central role. The secretion of $\mathrm{LH}$ pulses in female monkeys and ovariectomized sheep is inhibited by central administration of a selective kisspeptin antagonist (Roseweir et al. 2009), suggesting that GnRH pulse frequency is dependent on kisspeptin signaling. In goats, indirect evidence suggests the GnRH pulse generator is located in the caudal ARC, where kisspeptin cell bodies are located (Ohkura et al. 2009). Thus, in primates and ruminants, oestradiol negative feedback signals are sensed by kisspeptin neurons in the ARC that, in turn, stimulate GnRH neurons appropriately to control the pulsatile secretion of $\mathrm{GnRH}$. However, the exact mechanism through which kisspeptin can so profoundly affect GnRH secretion is only now beginning to emerge, primarily with the help of the 'KNDy hypothesis'.

\section{The KNDy hypothesis}

Despite the KNDy hypothesis being the latest chapter in the kisspeptin field, clues of its existence date back to the 1990s when neurokinin B (NKB, product of the TAC3 gene) expression in the ARC was correlated with LH concentrations in humans and rats (Rance \& Young 1991, Rance \& Bruce 1994). In sheep, these NKB neurons shared a close anatomical distribution with dynorphin neurons (Foradori et al. 2006) and all appear to contain ESR1 (Goubillon et al. 2000) and progesterone receptor (Foradori et al. 2002). With the discovery of kisspeptin the final piece of the puzzle fell into place and it was subsequently shown that a single population of neurons contained all three peptides - first demonstrated in sheep (Goodman et al. 2007) and then expanded to rodents (Navarro et al. 2009). This specific population of cells, now commonly referred to as 'KNDy neurons', has moved to the frontline in discussions of the control 
of GnRH secretion (Lehman et al. 2010, Goodman et al. 2013). KNDy neurons were showed to have remarkable reciprocal projections, forming a KNDy-KNDy network (Burke et al. 2006), with terminals also projecting predominantly to the median eminence (ME), but also to a lesser degree to the POA (Smith et al. 2011) (Fig. 2). These observations formed the foundation of the KNDy hypothesis and were further supported by the knowledge that KNDy neurons contained the NKB receptor (TACR3) and GnRH neurons do not (Amstalden et al. 2010). Studies in mice showed there is also potential for communication within and between KNDy neurons because they express NKB and dynorphin receptors (Navarro et al. 2009). Interestingly, they do not express Kiss1r mRNA (Smith et al. 2011) leading to the proposition that kisspeptin was the final output signal of the KNDy neuron. The essence of the KNDy hypothesis is that NKB acts as a 'pace-setter' for kisspeptin release, dynorphin acts as a 'brake', and kisspeptin acts as the final step in communication between the KNDy neurons and $\mathrm{GnRH}$ neurons, thus affecting changes in the pulsatile pattern of secretion of GnRH (Okamura et al. 2013).

The KNDy neurons and their fibres are well placed to fulfil the role of a 'pulse generator' that drives $\mathrm{GnRH}$ secretion. In the ewe: i) KNDy neurons receive feedback signals from sex steroids and express the required receptors (Smith 2013); ii) KNDy neurons express FOS during both surge and pulsatile secretion of LH (Smith et al. 2009a, Merkley et al. 2012); iii) LH pulse frequency is reduced by administration of NKB receptor antagonists into the ARC, but increased by administration of NKB and dynorphin receptor antagonists (Goodman et al. 2013); and iv) Kiss1r antagonists blocked the secretion of LH pulses (Roseweir et al. 2009). Furthermore, in the monkey, kisspeptin content in the ME correlates with GnRH pulses (Keen et al. 2008). Finally, periodic bursts of multiple-unit activity (referred to as 'MUA volleys') in the vicinity of KNDy neurons in goats are temporally associated with the secretion of LH pulses (Wakabayashi et al. 2010, Wakabayashi et al. 2013). Moreover, an icv administration of NKB induces and dynorphin inhibits MUA volleys. All of these observations are consistent with the basic tenets of the hypothesis that KNDy neurons act as a putative GnRH pulse generator.

Despite this evidence, there is still serious controversy in the literature. For example, there is debate about the role of KNDy neurons in inhibition of $\mathrm{GnRH}$ secretion by sex steroids, in both males and females, and in different species and about the mechanism through which three neuropeptides interact and are released with temporal specificity to change the pattern of secretion of a single $\mathrm{GnRH}$ pulse. There is also controversy surrounding the very existence of a ' $\mathrm{GnRH}$ pulse generator' in the brain - many researchers are of the view that KNDy neurons fulfil this role, while others reject the very notion of the existence of a "single" pulse generator arguing that is a property of a distributed network that includes GnRH neurons (Goodman et al. 2014). Regarding the latter, it should also be noted that the response to a constant infusion of kisspeptin - increased LH pulse frequency (George et al. 2011) - suggests that KNDy neuronal output (kisspeptin 'pulses') may not function as the 'GnRH pulse generator', but as a modulator of the pulses intrinsic to GnRH neurons (Martinez de la Escalera et al. 1992, Richter et al. 2002). On the other hand, data from rats (Roa et al. 2008), sheep (Caraty et al. 2007) and monkeys (Seminara et al. 2006) indicate that constant elevation of kisspeptin is unable to maintain sustained elevated $\mathrm{LH}$ secretion. Whether kisspeptin neurons truly drive GnRH pulses, or whether kisspeptin is simply a permissive signal to allow expression of $\mathrm{GnRH}$ pulses, needs to be rigorously tested.

\section{The role of kisspeptin in seasonal breeding}

In ovary-intact ewes, KISS1 mRNA expression in the ARC is higher during the breeding season than the non-breeding season (Wagner et al. 2008). As previously stated, the seasonal change in $\mathrm{GnRH}$ pulse frequency is the outcome of interactions between steroid-dependent and 
steroid-independent mechanisms, both of which appear to be mediated by kisspeptin neurons. With regard to the steroid-independent mechanism, the breeding season elevation in KISS1 is apparent in the absence of sex steroid feedback in ovariectomized ewes (Smith et al. 2007). With regard to the steroid dependent mechanism, KISS1 is also elevated during the breeding season in ovariectomized ewes provided with oestradiol replacement (Smith et al. 2008). Most importantly, the inhibitory effect of oestradiol on KISS1 expression in the ARC is greater during the non-breeding season than the breeding season (Smith et al. 2008), consistent with the view that the seasonal change in responsiveness to oestradiol is affected by changes in the response of kisspeptin neurons to oestradiol.

Kisspeptin neurons in the POA also appear to be regulated by season. A modest but significant increase in the number of POA kisspeptin neurons is apparent in ewes after they have been shifted into a short-day photoperiod, although this change was only significant when the data were corrected for the total number of neurons in the POA (Chalivoix et al. 2010). Importantly, this observation was made in ovariectomized-oestradiol treated ewes, indicating a photoperiod-driven change in oestradiol responsiveness in POA kisspeptin neurons, as observed in the ARC. However, other studies have led to the conclusion that kisspeptin in the POA is not regulated by seasonal status (Smith et al. 2007, Smith et al. 2008) - importantly, this work was done by two separate but collaborating laboratory groups, using both in situ hybridization and immunohistochemistry, and in ovariectomized ewes in the presence and absence of oestradiol (Smith et al. 2008). Our view is, therefore, that the two populations of kisspeptin neurons play different roles in the regulation of $\mathrm{GnRH}$ secretion in the ewe. In the ARC, there are more kisspeptin neurons and these mediate both negative and positive feedback regulation of GnRH secretion by oestradiol (Smith 2008, Smith 2009, Merkley et al. 2012), with the negative feedback action being key to the regulation of seasonal reproduction. In the POA, on the other hand, kisspeptin neurons appear to be involved only in positive feedback and therefore the induction of the preovulatory surge of $\mathrm{GnRH}$ and $\mathrm{LH}$ (Smith et al. 2009a, Hoffman et al. 2011, Merkley et al. 2012).

The combination of increases in KISS1 expression, and in the number of kisspeptin neurons during the transition from non-breeding to breeding season, suggests an increase in neuroanatomical communication between kisspeptin neurons and $\mathrm{GnRH}$ neurons. The number of $\mathrm{GnRH}$ neurons that receive 'input' (defined by the close apposition of kisspeptin terminals) and the number of kisspeptin appositions on each $\mathrm{GnRH}$ neuron, are higher during the breeding season than during the anoestrus season (Smith et al. 2008). The origin of these appositions is subject to considerable debate. Presumably, this extra kisspeptin input arises from the ARC, consistent with the increased KISS 1 expression in this region. However, previous data utilizing anterograde and retrograde tracers suggests that ARC kisspeptin neurons do not project directly to $\mathrm{GnRH}$ neurons, in contrast with POA kisspeptin neurons (Backholer et al. 2009). Indeed, few projections from the ARC terminate at GnRH neurons (Pompolo et al. 2001), and there are similar observations for mice (Wintermantel et al. 2006). It is, however, possible that neuronal tracing is not sufficiently sensitive to reveal appositions to specific neurons. In line with this, a large percentage of $\mathrm{GnRH}$ neurons in the ovine POA and $\mathrm{MBH}$ are shown to have appositions from kisspeptin terminals, which co-express dynorphin, thus confirming their origin from ARC KNDy neuronal population (Lehman et al. 2013).

In ewes, the $\mathrm{GnRH} / \mathrm{LH}$ response to kisspeptin is greater during the non-breeding season than during the breeding season (Smith et al. 2009b, Li et al. 2012). This difference might be a consequence of changes in the releasable pool of $\mathrm{GnRH}$ accumulating between pulses, which would be greater in the anoestrus season. A reduction in $\mathrm{GnRH} / \mathrm{LH}$ pulse frequency leads to an increase in LH pulse amplitude due to effects at the level of the gonadotroph (Clarke \& Cummins 
1985). Despite this, recent evidence shows that the expression of KISS1R on GnRH neurons is greater during the non-breeding season than during the breeding season ( $\mathrm{Li}$ et al. 2012). The role of this increase in responsiveness of $\mathrm{GnRH}$ neurons to kisspeptin during anoestrus is not clear, but one possibility is that it allows for a greater 'perception' of the increasing levels of ARC kisspeptin expression at the onset of the breeding season (Smith et al. 2007, Smith et al. 2008), enabling the return of pulsatile GnRH secretion.

\section{Can kisspeptin prevent seasonal anoestrous?}

Given the discussion above, a strong case can be made for an increase in kisspeptin signalling driving the return of $\mathrm{GnRH}$ pulses at the onset of the breeding season. If this were to be true, then we would expect exogenous administration of kisspeptin to reactivate the gonadotrophic axis and allow ovulation in ewes. This outcome was indeed demonstrated by two collaborating research groups using an intravenous infusion of kisspeptin over $48 \mathrm{~h}$ (Caraty et al. 2007). In anoestrus ewes, kisspeptin transiently restored LH concentrations and induced ovulation in the majority of animals (Caraty et al. 2007). It was proposed that the kisspeptin infusion induced a follicular phase-like state, culminating in oestradiol-positive feedback and ovulation. This was further detailed in a follow-up study, showing elevated oestradiol levels were a prerequisite for kisspeptin to induce ovulation (Sebert et al. 2010).

An interesting aspect to both these studies was that a peripheral infusion of kisspeptin was adequate for initiating ovulation despite the fact that kisspeptin acts centrally to stimulate $\mathrm{GnRH}$ neurons. In sheep, kisspeptin neurons extend down through the internal zone of the ME to the external zone and are thought to mingle with $\mathrm{GnRH}$ terminals outside the blood-brain barrier stimulating the release of $\mathrm{GnRH}$ (Smith et al. 2011). It is probable that kisspeptin in the periphery may cross the fenestrated capillaries to also stimulate the $\mathrm{GnRH}$ terminals. Equally, recent data (albeit in mice) has shown GnRH neurons extend complex highly branched dendritic trees to the organum vasculosum of the lamina terminalis (OVLT) outside the blood-brain barrier (Herde et al. 2011). Although a peripheral infusion offers a technological advantage over a cerebroventricular infusion, it still offers little for industry where extensive grazing systems are not conducive to reproductive technologies (Martin 2014).

In sheep, the introduction of a novel male stimulates the secretion of $\mathrm{GnRH}$ pulses in females during the non-breeding season, causing the resumption of follicle maturation and ovulation (Hawken et al. 2009). This 'male effect' has been well characterized in sheep and is known to be effected predominantly by the action of pheromones (Delgadillo et al. 2009) initiated through activation of the main and accessory olfactory systems (Hawken \& Martin 2012). Moreover, this naturally occurring phenomenon affect draws some similarities to the above-mentioned response to exogenous kisspeptin treatment. It is therefore not surprising that, in anoestrous ewes exposed to rams, there was an increase in the activation of kisspeptin neurons in the ARC, as detected by FOS protein expression (De Bond et al. 2013). Moreover, the administration of a kisspeptin antagonist completely blocked the response to male exposure, demonstrating the requirement of kisspeptin signaling. Given that the 'male effect' appears to rely on ARC kisspeptin neurons, the question remains as to whether activation of the KNDy network is driving the response. While this has not yet been addressed in sheep, a recent study in female goats showed that MUA-volleys in the vicinity of KNDy neurons and $\mathrm{LH}$ pulses are also stimulated acutely by pheromone exposure. Most importantly, this action was blocked by treatment with an NKB receptor antagonist (Sakamoto et al. 2013). Although at this stage circumstantial, and not immune to the uncertainty continuing to surround the KNDy hypothesis, as noted above, 
these results implicate the KNDy system in mediating the pheromone effect on GnRH secretion seen in anoestrous ewes (Fig. 3).

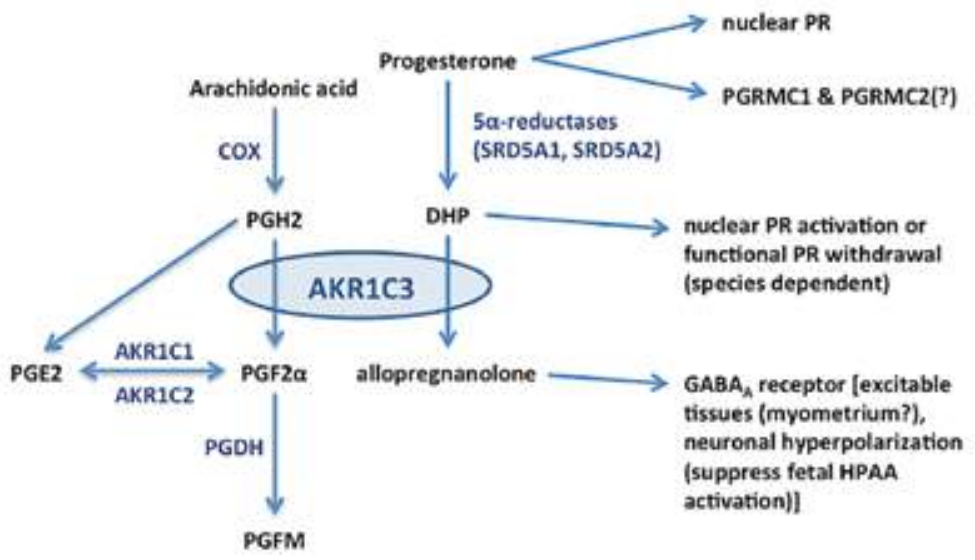

Fig. 3. Schematic representation of the possible signalling pathway leading to increased gonadotrophin-releasing hormone $(\mathrm{GnRH})$ pulses in ewes exposed to males. Male odor (indicated by the male symbol) results in activation of the main and accessory olfactory systems (MOB and AOB)(Hawken and Martin, 2012). This signal is transmitted, via the amygdala (AMG), to kisspeptin, neurokinin B (NKB), dynorphin (Dyn) neurons (KNDy neurons) in the arcuate nucleus (ARC) of the hypothalamus. KNDy neurons receive autoregulatory input from NKB and Dyn, forming a local circuit. To increase GnRH secretion, kisspeptin release is enhanced through NKB and a reduction in Dyn. The resultant increases in oestradiol release initiate the resumption of oestrous cycles.

\section{The pathway from photoperiod to kisspeptin neurons}

Photoperiod appears to be the major factor governing seasonal change in kisspeptin expression, as evidenced by studies using controlled light/dark cycles in seasonal rodents (Revel et al. 2007, Simonneaux et al. 2009) and sheep (Wagner et al. 2008, Chalivoix et al. 2010). When ewes were shifted from a short day photoperiod (8:16 h light/dark) to a long day photoperiod (16:8 $\mathrm{h}$ light/dark), KISS1 mRNA expression in the ARC declined (Wagner et al. 2008). Conversely, when ewes were shifted from long days (16:8 h light/dark) to short days (8:16 h light/dark), the number of identifiable kisspeptin neurons in the ARC increased (Chalivoix et al. 2010). Photoperiodic information is transduced into a neuroendocrine signal by the secretion of melatonin by the pineal gland at night. In ewes, removal of the pineal gland prevents the seasonal breeding response to photoperiod (Malpaux et al. 2002, Biebermann et al. 2006) and a similar response in seasonal rodents is linked to kisspeptin neurons (Greives et al. 2007, Ansel et al. 2010). In sheep, melatonin acts at the level of the premammillary and mediobasal hypothalamic areas (Malpaux et al. 1993, Malpaux et al. 1998), two regions that are near the ARC kisspeptin neurons. If such regulation does take place, it must be indirect because ARC kisspeptin neurons do not express the signaling form of the melatonin receptor (Li et al. 2011).

The pathway from photoperiod to kisspeptin neurons remains to be elucidated. One possibility is the dopaminergic neurons within the A14/A15 region (Goodman et al. 2010) 
that are recognised as inhibitors of LH pulse frequency during the non-breeding season (Meyer \& Goodman 1985, Havern et al. 1994). Moreover, they appear to only exert their influence during the non-breeding season and they are oestradiol-dependent (Meyer \& Goodman 1986). Oestradiol induces FOS protein expression in A14/A15 dopaminergic neurons during the nonbreeding season but not during the breeding season (Lehman et al. 1996). Most importantly, these cells send projections to the ARC (Havern et al. 1991) and thus potentially to kisspeptin neurons. Recently, ovine kisspeptin neurons were shown to possess the dopamine receptor (DRD2) that is responsible for the inhibition of LH secretion in anoestrous ewes (Goodman et al. 2012). Moreover, DRD2 antagonist treatment increased LH pulse frequency in ewes during the non-breeding season, but the effect was completely blocked by a central infusion of a kisspeptin antagonist (Goodman et al. 2012). These observations support a role for A14/ A15 dopaminergic neurons in relaying seasonal information to kisspeptin neurons. Where melatonin intervenes is yet to be determined.

\section{Conclusions}

Since 2003, kisspeptin has been in the spotlight of neuroendocrine research and remarkable advances in our understanding of fertility have been made, many utilising the ovine model. The weight of evidence indicates, but is yet to prove conclusively, that kisspeptin neurons, operating through the KNDy unit, play the role of a GnRH pulse generator. Equally, kisspeptin neurons are well placed to govern the seasonal switch in reproduction that occurs in sheep. Manipulation of the breeding season is possible with kisspeptin treatment and also the introduction of novel males, a phenomenon that may operate through KNDy neurons. The precise mechanisms and neuroanatomical pathway by which this is achieved remain to be determined.

\section{Acknowledgments}

The authors are supported by an Australian Research Council Project Grant (DP140102495).

\section{References}

Amstalden M, Coolen LM, Hemmerle AM, Billings HJ, Connors JM, Goodman RL \& Lehman MN 2010 Neurokinin 3 receptor immunoreactivity in the septal region, preoptic area and hypothalamus of the female sheep: colocalisation in neurokinin B cells of the arcuate nucleus but not in gonadotrophin-releasing hormone neurones. Journal of Neuroendocrinology 22 1-12.

Ansel L, Bolborea M, Bentsen AH, Klosen P, Mikkelsen JD \& Simonneaux V 2010 Differential regulation of kiss1 expression by melatonin and gonadal hormones in male and female Syrian hamsters. Journal of Biological Rhythms 25 81-91.

Backholer K, Smith JT \& Clarke IJ 2009 Melanocortins may stimulate reproduction by activating orexin neurons in the dorsomedial hypothalamus and kisspeptin neurons in the preoptic area of the ewe. Endocrinology 150 5488-5497.

Biebermann $H$, Castaneda TR, van Landeghem $F$, von Deimling A, Escher F, Brabant G, Hebebrand J, Hinney
A, Tschop MH, Gruters A \& Krude H 2006 A role for beta-melanocyte-stimulating hormone in human bodyweight regulation. Cell Metabolism 3 141-146.

Blache D, Fabre-Nys CJ \& Venier G 1991 Ventromedial hypothalamus as a target for oestradiol action on proceptivity, receptivity and luteinizing hormone surge of the ewe. Brain Research 546 241-249.

Burke MC, Letts PA, Krajewski SJ \& Rance NE 2006 Coexpression of dynorphin and neurokinin B immunoreactivity in the rat hypothalamus: Morphologic evidence of interrelated function within the arcuate nucleus. Journal of Comparative Neurology 498 712-726.

Caraty A, Fabre-Nys C, Delaleu B, Locatelli A, Bruneau G, Karsch FJ \& Herbison A 1998 Evidence that the mediobasal hypothalamus is the primary site of action of estradiol in inducing the preovulatory gonadotropin releasing hormone surge in the ewe. Endocrinology 139 1752-1760. 
Caraty A, Smith JT, Lomet D, Ben Said S, Morrissey A, Cognie J, Doughton B, Baril G, Briant C \& Clarke IJ 2007 Kisspeptin synchronizes preovulatory surges in cyclical ewes and causes ovulation in seasonally acyclic ewes. Endocrinology 148 5258-5267.

Chalivoix S, Bagnolini A, Caraty A, Cognie J, Malpaux B \& Dufourny L 2010 Effects of photoperiod on kisspeptin neuronal populations of the ewe diencephalon in connection with reproductive function. Journal of Neuroendocrinology 22 110-118.

Clarke IJ 1988 Gonadotrophin-releasing hormone secretion $(\mathrm{GnRH})$ in anoestrous ewes and the induction of $\mathrm{GnRH}$ surges by oestrogen. Journal of Endocrinology 117 355-360.

Clarke IJ 2011 Control of GnRH secretion: one step back. Frontiers in Neuroendocrinology 32 367-375.

Clarke IJ \& Caraty A 2013 Kisspeptin and seasonality of reproduction. Advances in Experimental Medicine and Biology 784 411-430.

Clarke IJ \& Cummins JT 1985 GnRH pulse frequency determines LH pulse amplitude by altering the amount of releasable $\mathrm{LH}$ in the pituitary glands of ewes. Journal of Reproduction and Fertility 73 425-431.

Clarke IJ \& Pompolo S 2005 Synthesis and secretion of $\mathrm{GnRH}$. Animal Reproduction Science 88 29-55.

De Bond JA, Li Q, Millar RP, Clarke IJ \& Smith JT 2013 Kisspeptin signaling is required for the luteinizing hormone response in anestrous ewes following the introduction of males. PLoS One 8 e57972.

Delgadillo JA, Gelez H, Ungerfeld R, Hawken PA \& Martin GB 2009 The 'male effect' in sheep and goats-revisiting the dogmas. Behavioural Brain Research 200 304-314.

Estrada KM, Clay CM, Pompolo S, Smith JT \& Clarke IJ 2006 Elevated KiSS-1 expression in the arcuate nucleus prior to the cyclic preovulatory gonadotrophin-releasing hormone/lutenising hormone surge in the ewe suggests a stimulatory role for kisspeptin in oestrogen-positive feedback. Journal of Neuroendocrinology 18 806-809.

Foradori CD, Amstalden M, Goodman RL \& Lehman MN 2006 Colocalisation of dynorphin a and neurokinin B immunoreactivity in the arcuate nucleus and median eminence of the sheep. Journal of Neuroendocrinology 18 534-541.

Foradori CD, Coolen LM, Fitzgerald ME, Skinner DC, Goodman RL \& Lehman MN 2002 Colocalization of progesterone receptors in parvicellular dynorphin neurons of the ovine preoptic area and hypothalamus. Endocrinology 143 4366-4374.

Franceschini I, Lomet D, Cateau M, Delsol G, Tillet Y \& Caraty A 2006 Kisspeptin immunoreactive cells of the ovine preoptic area and arcuate nucleus co-express estrogen receptor alpha. Neuroscience Letters $\mathbf{4 0 1}$ 225-230.

George JT, Veldhuis JD, Roseweir AK, Newton CL, Faccenda E, Millar RP \& Anderson RA 2011 Kisspeptin-10 is a potent stimulator of $\mathrm{LH}$ and increases pulse frequency in men. The Journal of Clinical Endocrinology and Metabolism 96 E1228-1236.

Goodman RL, Coolen LM \& Lehman MN 2014. Unraveling the mechanism of action of the $\mathrm{GnRH}$ pulse generator: a possible role for kisspeptin/neurokinin B/dynorphin (KNDy) neurons. In: Conn, U.-A. A. (ed.) Cellular Endocrinology in Health and Disease.

Goodman RL, Hileman SM, Nestor CC, Porter KL, Connors JM, Hardy SL, Millar RP, Cernea M, Coolen LM \& Lehman MN 2013 Kisspeptin, neurokinin B, and dynorphin act in the arcuate nucleus to control activity of the GnRH pulse generator in ewes. Endocrinology 154 4259-4269.

Goodman RL, Jansen HT, Billings HJ, Coolen LM \& Lehman MN 2010 Neural systems mediating seasonal breeding in the ewe. Journal of Neuroendocrinology 22 674-681.

Goodman RL, Lehman MN, Smith JT, Coolen LM, de Oliveira CV, Jafarzadehshirazi MR, Pereira A, Iqbal J, Caraty A, Ciofi P \& Clarke IJ 2007 Kisspeptin neurons in the arcuate nucleus of the ewe express both dynorphin A and neurokinin B. Endocrinology 148 5752-5760.

Goodman RL, Maltby MJ, Millar RP, Hileman SM, Nestor CC, Whited B, Tseng AS, Coolen LM \& Lehman MN 2012 Evidence that dopamine acts via kisspeptin to hold GnRH pulse frequency in check in anestrous ewes. Endocrinology 153 5918-5927.

Gottsch ML, Cunningham MJ, Smith JT, Popa SM, Acohido BV, Crowley WF, Seminara S, Clifton DK \& Steiner RA 2004 A role for kisspeptins in the regulation of gonadotropin secretion in the mouse. Endocrinology 145 4073-4077.

Gottsch ML, Navarro VM, Zhao Z, Glidewell-Kenney C, Weiss J, Jameson JL, Clifton DK, Levine JE \& Steiner RA 2009 Regulation of Kiss 1 and dynorphin gene expression in the murine brain by classical and nonclassical estrogen receptor pathways. The Journal of Neuroscience $\mathbf{2 9}$ 9390-9395.

Goubillon ML, Forsdike RA, Robinson JE, Ciofi P, Caraty A \& Herbison AE 2000 Identification of neurokinin B-expressing neurons as an highly estrogen-receptive, sexually dimorphic cell group in the ovine arcuate nucleus. Endocrinology 141 4218-4225.

Greives TJ, Mason AO, Scotti MA, Levine J, Ketterson ED, Kriegsfeld LJ \& Demas GE 2007 Environmental control of kisspeptin: implications for seasonal reproduction. Endocrinology 148 1158-1166.

Havern RL, Whisnant CS \& Goodman RL 1991 Hypothalamic sites of catecholamine inhibition of luteinizing hormone in the anestrous ewe. Biology of Reproduction 44 476482.

Havern RL, Whisnant CS \& Goodman RL 1994 Dopaminergic structures in the ovine hypothalamus mediating estradiol negative feedback in anestrous ewes. Endocrinology 134 1905-1914.

Hawken PA, Jorre TJ, Rodger J, Esmaili T, Blache D \& Martin GB 2009 Rapid induction of cell proliferation in the adult female ungulate brain (Ovis aries) associated with activation of the reproductive axis by exposure to unfamiliar males. Biology of Reproduction 80 1146-1151.

Hawken PA \& Martin GB 2012 Sociosexual stimuli and gonadotropin-releasing hormone/luteinizing hormone secretion in sheep and goats. Domestic Animal Endocrinology 43 85-94.

Herde MK, Geist K, Campbell RE \& Herbison AE 2011 
Gonadotropin-releasing hormone neurons extend complex highly branched dendritic trees outside the blood-brain barrier. Endocrinology 152 3832-3841.

Hoffman GE, Le WW, Franceschini I, Caraty A \& Advis JP 2011 Expression of fos and in vivo median eminence release of $\mathrm{LHRH}$ identifies an active role for preoptic area kisspeptin neurons in synchronized surges of $\mathrm{LH}$ and LHRH in the ewe. Endocrinology 152 214-222.

Karsch FJ, Goodman RL \& Legan SJ 1980 Feedback basis of seasonal breeding: test of an hypothesis. Journal of Reproduction and Fertility 58 521-535.

Keen KL, Wegner FH, Bloom SR, Ghatei MA \& Terasawa E 2008 An increase in kisspeptin-54 release occurs with the pubertal increase in luteinizing hormone-releasing hormone- 1 release in the stalk-median eminence of female rhesus monkeys in vivo. Endocrinology 149 4151-4157.

Lehman MN, Coolen LM \& Goodman RL 2010 Minireview: kisspeptin/neurokinin B/dynorphin (KNDy) cells of the arcuate nucleus: a central node in the control of gonadotropin-releasing hormone secretion. Endocrinology 151 3479-3489.

Lehman MN, Durham DM, Jansen HT, Adrian B \& Goodman RL 1996 Dopaminergic A14/A15 neurons are activated during estradiol negative feedback in anestrous, but not breeding season, ewes. Endocrinology 137 4443-4450.

Lehman MN, Hileman SM \& Goodman RL 2013 Neuroanatomy of the kisspeptin signaling system in mammals: comparative and developmental aspects. Advances in Experimental Medicine and Biology 784 27-62.

Li Q, Rao A, Pereira A, Clarke IJ \& Smith JT 2011 Kisspeptin cells in the ovine arcuate nucleus express prolactin receptor but not melatonin receptor. Journal of Neuroendocrinology 23 871-882.

Li Q, Roa A, Clarke IJ \& Smith JT 2012 Seasonal variation in the gonadotropin-releasing hormone response to kisspeptin in sheep: possible kisspeptin regulation of the kisspeptin receptor. Neuroendocrinology 96 212-221.

Malpaux B, Daveau A, Maurice F, Gayrard V \& Thiery JC 1993 Short-day effects of melatonin on luteinizing hormone secretion in the ewe: evidence for central sites of action in the mediobasal hypothalamus. Biology of Reproduction 48 752-760.

Malpaux B, Daveau A, Maurice-Mandon F, Duarte G \& Chemineau P 1998 Evidence that melatonin acts in the premammillary hypothalamic area to control reproduction in the ewe: presence of binding sites and stimulation of luteinizing hormone secretion by in situ microimplant delivery. Endocrinology 139 1508-1516.

Malpaux B, Tricoire H, Mailliet F, Daveau A, Migaud M, Skinner DC, Pelletier J \& Chemineau P 2002. Melatonin and seasonal reproduction: understanding the neuroendocrine mechanisms using the sheep as a model. In: Skinner, D. C., Evans, N. P. \& Doberska, C. (eds.) Large Mammals as Neuroendocrine Models, pp. 167-179.

Martin GB 1984 Factors affecting the secretion of luteinizing hormone in the ewe. Biological Reviews of the Cambridge Philosophical Society 59 1-87.

Martin GB 2014 An australasian perspective on the role of reproductive technologies in world food production. Advances in Experimental Medicine and Biology 752 181-197.

Martin GB, Scaramuzzi RJ \& Henstridge JD 1983 Effects of oestradiol, progesterone and androstenedione on the pulsatile secretion of luteinizing hormone in ovariectomized ewes during spring and autumn. Journal of Endocrinology 96 181-193.

Martinez de la Escalera G, Choi AL \& Weiner RI 1992 Generation and synchronization of gonadotropinreleasing hormone $(\mathrm{GnRH})$ pulses: intrinsic properties of the GT1-1 GnRH neuronal cell line. Proceedings of the National Academy of Sciences of the United States of America 89 1852-1855.

Merkley CM, Porter KL, Coolen LM, Hileman SM, Billings HJ, Drews S, Goodman RL \& Lehman MN 2012 KNDy (kisspeptin/neurokinin B/dynorphin) neurons are activated during both pulsatile and surge secretion of $\mathrm{LH}$ in the ewe. Endocrinology 153 5406-5414.

Meyer SL \& Goodman RL 1985 Neurotransmitters involved in mediating the steroid-dependent suppression of pulsatile luteinizing hormone secretion in anestrous ewes: effects of receptor antagonists. Endocrinology 116 2054-2061.

Meyer SL \& Goodman RL 1986 Separate neural systems mediate the steroid-dependent and steroid-independent suppression of tonic luteinizing hormone secretion in the anestrous ewe. Biology of Reproduction 35 562-571.

Migaud M, Daveau A \& Malpaux B 2005 MTNR1A melatonin receptors in the ovine premammillary hypothalamus: day-night variation in the expression of the transcripts. Biology of Reproduction 72 393-398.

Navarro VM, Gottsch ML, Chavkin C, Okamura H, Clifton DK \& Steiner RA 2009 Regulation of gonadotropinreleasing hormone secretion by kisspeptin/dynorphin/ neurokinin B neurons in the arcuate nucleus of the mouse. The Journal of Neuroscience 29 11859-11866.

Oakley AE, Clifton DK \& Steiner RA 2009 Kisspeptin signaling in the brain. Endocr Rev 30 713-743.

Ohkura S, Takase K, Matsuyama S, Mogi K, Ichimaru T, Wakabayashi Y, Uenoyama Y, Mori Y, Steiner RA, Tsukamura H, Maeda KI \& Okamura H 2009 Gonadotrophin-releasing hormone pulse generator activity in the hypothalamus of the goat. Journal of Neuroendocrinology 21 813-821.

Okamura H, Tsukamura H, Ohkura S, Uenoyama Y, Wakabayashi Y \& Maeda K 2013 Kisspeptin and GnRH pulse generation. Advances in Experimental Medicine and Biology 784 297-323.

Pompolo S, Rawson JA \& Clarke IJ 2001 Projections from the arcuate/ventromedial region of the hypothalamus to the preoptic area and bed nucleus of stria terminalis in the brain of the ewe; lack of direct input to gonadotropinreleasing hormone neurons. Brain Research 904 1-12.

Rance NE \& Bruce TR 1994 Neurokinin B gene expression is increased in the arcuate nucleus of ovariectomized rats. Neuroendocrinology 60 337-345.

Rance NE \& Young WS, 3rd 1991 Hypertrophy and increased gene expression of neurons containing neurokinin-B and substance-P messenger ribonucleic acids in the 
hypothalami of postmenopausal women. Endocrinology 128 2239-2247.

Revel FG, Ansel L, Klosen P, Saboureau M, Pevet P, Mikkelsen JD \& Simonneaux V 2007 Kisspeptin: A key link to seasonal breeding. Reviews in Endocrine and Metabolic Disorders 8 57-65.

Richter TA, Keen KL \& Terasawa E 2002 Synchronization of $\mathrm{Ca}(2+)$ oscillations among primate LHRH neurons and nonneuronal cells in vitro. Journal of Neurophysiology 88 1559-1567.

Roa J, Vigo E, Garcia-Galiano D, Castellano JM, Navarro VM, Pineda R, Dieguez C, Aguilar E, Pinilla L \& TenaSempere $\mathbf{M} 2008$ Desensitization of gonadotropin responses to kisspeptin in the female rat: analyses of $\mathrm{LH}$ and FSH secretion at different developmental and metabolic states. American Journal of Physiology Endocrinology and Metabolism 294 E1088-1096.

Roseweir AK, Kauffman AS, Smith JT, Guerriero KA, Morgan K, Pielecka-Fortuna J, Pineda R, Gottsch ML, TenaSempere M, Moenter SM, Terasawa E, Clarke IJ, Steiner RA \& Millar RP 2009 Discovery of potent kisspeptin antagonists delineate physiological mechanisms of gonadotropin regulation. The Journal of Neuroscience 29 3920-3929.

Sakamoto K, Wakabayashi Y, Yamamura T, Tanaka T, Takeuchi Y, Mori Y \& Okamura H 2013 A population of kisspeptin/neurokinin B neurons in the arcuate nucleus may be the central target of the male effect phenomenon in goats. PLoS One 8 e81017.

Scaramuzzi RJ \& Martin GB 2008 The importance of interactions among nutrition, seasonality and socio-sexual factors in the development of hormone-free methods for controlling fertility. Reproduction in Domestic Animals 43 Suppl 2 129-136.

Sebert ME, Lomet D, Said SB, Monget P, Briant C, Scaramuzzi RJ \& Caraty A 2010 Insights into the mechanism by which kisspeptin stimulates a preovulatory LH surge and ovulation in seasonally acyclic ewes: Potential role of estradiol. Domestic Animal Endocrinology 38 289-298.

Seminara SB, Dipietro MJ, Ramaswamy S, Crowley WF, Jr. \& Plant TM 2006 Continuous human metastin 4554 infusion desensitizes $\mathrm{G}$ protein-coupled receptor 54-induced gonadotropin-releasing hormone release monitored indirectly in the juvenile male Rhesus monkey (Macaca mulatta): a finding with therapeutic implications. Endocrinology 147 2122-2126.

Simerly RB 2002 Wired for reproduction: organization and development of sexually dimorphic circuits in the mammalian forebrain. Annual Review of Neuroscience 25 507-536.

Simonneaux V, Ansel L, Revel FG, Klosen P, Pevet P \& Mikkelsen JD 2009 Kisspeptin and the seasonal control of reproduction in hamsters. Peptides 30 146-153.

Smith JT 2008 Kisspeptin signalling in the brain: steroid regulation in the rodent and ewe. Brain Research Reviews 57 288-298.

Smith JT 2009 Sex steroid control of hypothalamic Kiss1 expression in sheep and rodents: comparative aspects. Peptides 30 94-102.
Smith JT 2013 Sex steroid regulation of kisspeptin circuits. Advances in Experimental Medicine and Biology $\mathbf{7 8 4}$ 275-295.

Smith JT, Clay CM, Caraty A \& Clarke IJ 2007 KiSS1 messenger ribonucleic acid expression in the hypothalamus of the ewe is regulated by sex steroids and season. Endocrinology 148 1150-1157.

Smith JT, Coolen LM, Kriegsfeld LJ, Sari IP, Jaafarzadehshirazi MR, Maltby M, Bateman K, Goodman RL, Tilbrook AJ, Ubuka T, Bentley GE, Clarke IJ \& Lehman MN 2008 Variation in kisspeptin and RFamide-related peptide (RFRP) expression and terminal connections to gonadotropin-releasing hormone neurons in the brain: a novel medium for seasonal breeding in the sheep. Endocrinology 149 5770-5782.

Smith JT, Cunningham MJ, Rissman EF, Clifton DK \& Steiner RA 2005 Regulation of Kiss 1 gene expression in the brain of the female mouse. Endocrinology 146 3686-3692.

Smith JT, Li Q, Pereira A \& Clarke IJ 2009a Kisspeptin neurons in the ovine arcuate nucleus and preoptic area are involved in the preovulatory luteinizing hormone surge. Endocrinology 150 5530-5538.

Smith JT, Li Q, Yap KS, Shahab M, Roseweir AK, Millar RP \& Clarke IJ 2011 Kisspeptin is essential for the full preovulatory LH surge and stimulates $\mathrm{GnRH}$ release from the isolated ovine median eminence. Endocrinology 152 1001-1012.

Smith JT, Popa SM, Clifton DK, Hoffman GE \& Steiner RA 2006 Kiss 1 neurons in the forebrain as central processors for generating the preovulatory luteinizing hormone surge. The Journal of Neuroscience 26 6687-6694.

Smith JT, Saleh SN \& Clarke IJ 2009b Seasonal and cyclical change in the luteinizing hormone response to kisspeptin in the ewe. Neuroendocrinology 90 283-291.

Wagner GC, Johnston JD, Clarke IJ, Lincoln GA \& Hazlerigg DG 2008 Redefining the limits of day length responsiveness in a seasonal mammal. Endocrinology 149 32-39.

Wakabayashi Y, Nakada T, Murata K, Ohkura S, Mogi K, Navarro VM, Clifton DK, Mori Y, Tsukamura H, Maeda K, Steiner RA \& Okamura H 2010 Neurokinin B and dynorphin a in kisspeptin neurons of the arcuate nucleus participate in generation of periodic oscillation of neural activity driving pulsatile gonadotropin-releasing hormone secretion in the goat. The Journal of Neuroscience 30 3124-3132.

Wakabayashi Y, Yamamura T, Sakamoto K, Mori Y \& Okamura H 2013 Electrophysiological and morphological evidence for synchronized GnRH pulse generator activity among Kisspeptin/neurokinin B/dynorphin A (KNDy) neurons in goats. Journal of Reproduction and Development 59 40-48.

Wintermantel TM, Campbell RE, Porteous R, Bock D, Grone HJ, Todman MG, Korach KS, Greiner E, Perez CA, Schutz G \& Herbison AE 2006 Definition of estrogen receptor pathway critical for estrogen positive feedback to gonadotropin-releasing hormone neurons and fertility. Neuron 52 271-280. 